\title{
Leszek Żyliński
}

\section{APPROACHING EUROPE. CONCEPTIONS OF GERMAN INTELLECTUALS IN THE 20 ${ }^{\mathrm{TH}}$ AND $21^{\mathrm{ST}}$ CENTURIES}

The discovery and building of Europe by Europeans has been a process to which writers and intellectuals contributed as much as rulers and politicians. In German Lands, lacking a political centre until the unification by Prussia in 1871, the process of joining European projects long remained - understandably - in the sphere of ideas rather than strictly political action.

After the early modern 'Republique des Lettres' and the Enlightenment search for 'eternal peace' in a suitable political system, the $19^{\text {th }}$ century saw a turn among German-speaking thinkers towards the past, by mythologizing the old Holy Roman Empire. The fulfilment of its universal mission was to be based on Christian traditions and culture. German writers, living in dozens of duchies and kingdoms of various sizes, and deprived of the legal framework of the Reich dissolved by Napoleon, began to long for a universal holistic idea. This was particularly visible in the first decades of the $19^{\text {th }}$ century in the works of Romantics such as Novalis, Friedrich Schlegel, Adam Müller or Franz von Baader. On the other hand, the dynamic ideology of nationalism, enhanced by the Borussian/Prussian? delight at its own nation-state, discouraged the Germans (especially after 1871) from thinking in cosmopolitan and all-European categories. No serious debate was undertaken on the republican project of Claude-Henri de Saint-Simon or on the European views of Victor Hugo or Charles Mackay. The idea of a United States of Europe or any kind of federation of free European nations was popular only among German expatriates (Josef Görres, Heinrich Heine, Ludwig Börne). They propagated - contrary to the political reality of the Holy Alliance - emancipation projects expected to give rise to European patriotism in the future. ${ }^{1}$

${ }^{1}$ For more on this, see: L. Żyliński, Europa w niemieckiej myśli XIX-XXI wieku, Wyd. UMK, Toruń 2012. 
In the German-language literature, the most interesting projects for a unified Europe did not appear until after the First World War. The 1914-1918 hecatomb, employing the ultramodern war technology and the propaganda of hate, resulted in radical revisions of views among intellectuals. Back in 1914 the Germans greeted the outbreak of war with joy. They saw the war mainly as a crusade of the dynamic German spirit, intent on overthrowing the stale status quo and on strengthening German culture against the 'shopkeeper spirit' of the capitalist West. They perceived this spirit as embodied by Great Britain, striving at all costs to preserve its assets. This way of thinking was verbalized in a model fashion by the future Nobel prizewinner Thomas Mann. In his lengthy 1918 essay Betrachtungen eines Unpolitischen, he presented German culture - with its form, style and community spirit - as an emanation of the European spirit and contrasted it with western values based on money, enlightenment and individualistic democracy.

Another German attempt to find and realize Europeanness was the concept of 'Mitteleuropa' presented in 1915 by the theologian and liberal politician Friedrich Naumann in his book of the same title. ${ }^{2}$ He assumed that the war in progress would give rise to a new confederation of states in the middle of Europe as 'historical necessity' and expression of 'mental reorientation'. The expected new union would not only secure victory in the battle with the West and with Russia, but also create and consolidate a new European power. The envisaged Central European community (ultimately 'a Central European state') would stretch 'from the North Sea and the Baltic to the Alps, the Adriatic and the southern reaches of the Danubian Lowland.' Although Naumann wanted to win the Poles, Hungarians and Czechs over to his idea, he made it clear that the core of Mitteleuropa would be German and that the character of the new country would be determined by 'the German economic confession.'

The military defeat of Germany coincided with the downfall of the whole continent, which began losing its primacy in the world. For German intellectuals, this epoch-making event marked the decline of European civilization. Such was the position of prominent writers like Hugo von Hofmannsthal, Hermann Hesse or Heinrich Mann. For them, the war and the following political confusion constituted a shocking experience. Europe had tragically distanced itself from the substance of its great spirit, from its essence and grandeur. For example, Hofmannsthal distinguished three phases of Europe's greatness: the community of Christians, the antiquity-rooted Latin-based Renaissance, and -'the highest of them all - German humanism', expressed in the works of Herder, Schiller, Novalis, Humboldt and Goethe. In the second half of the $19^{\text {th }}$ century - he claimed - the notion of Europe became stunted and lost its vigour and integrability. This gradual decline was

\footnotetext{
${ }^{2}$ F. Naumann, Mitteleuropa, Berlin 1915.
} 
evidenced by successive conflicts between European superpowers, the separation of Russia dominated by the spirit of Dostoevsky and Pan-Slavists, and the western 'new reality', based on the primacy of money and socialization of the state. ${ }^{3}$

However, the conclusions drawn from Hofmannsthal's diagnosis varied. Oswald Spengler, author of The Decline of the West - arguably the most popular historiosophic book of the interwar period - in his 'morphology of universal history' depicted Europe as leaving the stage, 'an empty sound.' Likewise Hermann Hesse, in his essay The Brothers Karamazov, or the Downfall of Europe, presented a pessimistic picture of old Europe crumbling under the pressure of the 'Russian man': 'It seems to me that European and especially German youth are destined to find their greatest writer in Dostoevsky - not in Goethe, not even in Nietzsche. ${ }^{3}$ Heinrich Mann, for his part, focused on German-French reconciliation, seeing it as a precondition for the unity of the continent. He warned, however, against any attempts at unification under the auspices of a spiritless capitalism which, in one way or another, is likely to appropriate this idea as well. He proposed that people of the spirit, disappointed with how the Catholic Church or communism went about righting the world, should found a new church. 'We need to set up a new church of our own,' suggested Mann, 'to establish equality among nations and to unify Europe. The future of this church will depend on faith: 'The faith is Europe and the gospel is its unity.'

In 1923, a young writer by the name of Richard Nikolaus von Coudenhove-Kalergi published his book entitled Pan-Europa, presenting a detailed unification plan for the continent. ${ }^{6}$ In his opinion it was essential to put an end to the nationalistic stupefaction of Europeans. At the same time, he saw a unified Europe as potentially one of the five world super powers. He attributed the downfall of Europe - the culmination of the war - from the world view crisis into which Europeans fell when they lost their nobility of spirit, as they had acknowledged the democratic principle of equality in state politics. The hegemony of Europe, he claimed, had ended once and for all, 'pushing it from the centre of the world to its periphery.' The only hope for the continent was in the creation of a United States of Europe. This would be the ultimate goal in a process which should start with a pan-European conference, followed by an alliance of all European democracies, to be strengthened later by a pan-European customs union and a state union from which Pan-Europa would develop.

For Coudenhove-Kalergi Pan-Europa, a political framework for Europe, would embrace all 'democratic and semi-democratic continental countries,' excluding Great Britain (because of the global dimension of the British Empire)

${ }^{3}$ H. v. Hofmannsthal, Rzut oka na stan europejskiego ducha, [in:] Europejskie wizje pisarzy niemieckich wXX wieku, red. L. Żyliński, Wydawnictwo Poznańskie ${ }_{2}$ Poznań 2003, p. 72-74.

${ }^{4}$ H. Hesse, 'Bracia Karamazow' albo zmierzch Europy, [in:] Europejskie wizje..., p. 61-71.

${ }^{5}$ H. Mann, Europa, Reich über den Reichen, „Neue Rundschau”1923, Nr. 34, p. 577-602.

${ }^{6}$ R.N. Coudenhove-Kalergi, Pan-Europa, Wien 1923. 
and Russia (because it was the centre of a different civilization and because of its dictatorial system of government). The author distinguished five emerging superpowers, which he called 'global areas of power': American, British, Russian, East Asian and European.' Ultimately a European nation would emerge, yet under a new definition; he called the dogma of a nation built on blood relationship as a harmful myth in the European mix. Kalergi called nations 'communities of spirit' and espoused fighting against ethnic chauvinism by highlighting the European dimension of each European culture. 'National chauvinism cannot be defeated by some abstract internationalism but through common understanding that all national cultures are integral parts of one homogeneous European culture. To understand this European unity of culture, each nation needs to get to know and to evaluate better the spiritual grandeur of its neighbours, to understand how much it owes or may owe them. It is through this process that a 'European patriotism' might emerge.'

It must be said that for an outsider without a political power base, Coudenhove-Kalergi's idea was a huge success. In the 1920s the advocates of Pan-Europa included politicians such as French Foreign Minister Aristide Briand, Czechoslovak Foreign Minister Edvard Beneš, or Chancellor of Austria Ignaz Seipel. The concept drew a lively response from German writers and thinkers. In general it was supported by, e.g., Gerhart Hauptmann, Kurt Hiller, Hugo von Hofmannsthal, Hermann Keyserling, Heinrich and Thomas Mann, Rudolf Pannwitz and Artur Schnitzler, although some of them did not approve of the exclusion of the British. In the 1930's, owing to the political changes taking place, Coudenhove-Kalergi and his movement accepted more clearly the German position on the revision of the Treaty of Versaille. The next pan-European congresses were held in Berlin (1930), Basel (1932) and again in Vienna (1935), but politically the influence of the movement was waning as frictions increased among intellectuals, and not only in Germany. Consequently, both the construction of Heinrich Mann's 'church' and Coudenhove-Kalergi's Pan-Europa were becoming more and more elusive.

Confronted by the growing political extremism of the 1930s, Pan-Europa proved too weak. The totalitarianisms and national chauvinisms made more effective use of the fanatical masses. The tragic European experience of the twelve years of the Third Reich served to pushed the clear-headed part of Germans even more towards the positions of European solidarity, with the peaceful unity of the continent as its central idea. Here, reflection on European traditions meets with criticism of that form of German culture which saw the German uniqueness in its separate historical and political development and in its anti-western bias. For post-Hitler German intellectuals, it was important that the category of nation be demythologized. After 1945 this was made easier, and it was in accord with the general perception that Nazism and World War II had totally discredited, for the Germans, the model of a state based on national egoism. Post-national 
projects were gaining ground, which either saw West Germany anchored in an integrating democratic Europe or which - in a different ideological context - called for creating an internationalist communist bloc in East Germany. For Germans, and not only writers, European integration was an idea aimed at guaranteeing peace and freedom, life in truth, and wealth of spirit. German intellectuals were in favour of a Europe anchoring Germany in western values. They saw Europe as the chance to say a definite farewell to the unfortunate concepts of Sonderweg and Mittlellage. After the criminal explosion of nationalism, the (West) German society accepted this intellectual offer quite willingly. While being authentically attractive, it allowed them to forget about the recent period of disgrace, the German responsibility for National Socialism, as well as provided an escape through taking on a new identity of a western citizen.

Years later, Hans Magnus Enzensberger quite aptly characterized the West German approach to the European issue in the 1950s. As Germans did not like to show off their German identity, they chose the other, morally unburdening one. The European project 'promised a compensation for the extermination of the Reich, and even guaranteed a better (though still vague) future. Besides, the idea of Europe was promising to represent something ideal, ideological or idealistic, and so it was simply predestined to add some solemnity to the dry process of material reconstruction. Everybody could fill in the term with their own notions. ${ }^{7}$

The Germans became, for the most part, the most ardent believers in 'Europe'. Their European identification, and constitutional patriotism based on western values became an antidote to any resurgence of nationalism and worked well in a divided Europe and a divided Germany.

Following Germany's 1990 unification, the new situation forced a revision of the European project. The united Germany saw itself as permanently anchored in a political Europe; one which was, unavoidably, in a state of flux. The writer Hans Magnus Enzensberger was sceptical about 'the Brussels-run Europe' and its bureaucracy. He agreed with the philosopher Peter Sloterdijk about abandoning 'the absence from great power politics' by Europeans and starting to work on 'a metamorphosis of the empire principle.' Sloterdijk would like to see Europe as a 'multinational federation' capable of taking up the challenges of the present-day world. Jürgen Habermas projects the political integration of Europe through the creation of a European public opinion and ultimately 'a nation of citizens' as opposed to 'a nation of compatriots.' The London-based sociologist Ralf Dahrendorf warns against dividing Europeans, via the newly-introduced euro currency, into a European core and and a European periphery. Also, from the British perspective, he tries to bring it home to the Germans that they are quite alone in their rejection of the nation state. 'The German leaders keep assuring us of the end of the nation

${ }^{7}$ H.M. Enzensberger, Bruksela czy Europa - jedno z dwóch, [in:] Europejskie wizje..., p. 262-267. 
state and of its replacement by the European Union. Some go as far as to say that there is no German national interest any more and that all German interests are from now on European.' The Germans' readiness to be the best Europeans - says Dahrendorf - worries other nations.

So when in 2000 the German Foreign Minister Joschka Fischer formulated a far-reaching idea of crowning the European integration after the EU expansion, he met with a cold reception in other capitals. ${ }^{8}$ Fisher would welcome a sort of a European Federation. Being realistic, he does not assume that nation states must disappear: 'The completion of the European integration will be successful if it is done by dividing sovereignty between Europe and the nation state.' Fisher knew that his idea was a kind of 'new European founding act', and it was so interpreted in other European capitals and by public opinion. The project of a European federation of nation states provoked divergent feelings and comments. Some warned against creating a European superstate, others saw it from the angle of their own negative historical experience with the Germans.

Such a reaction made many German intellectuals realize the historically-grounded incongruity of political models, especially the incompatibility of the German, British and French visions of a united Europe. Given the different political mentalities of the main European actors, the proposed federation is hard to imagine. There still exist traditional national differences between: 1) the federal conception - favoured by Germany - with the primacy of law and tradition which refers to the historical notion of an all-European empire i.e. Reich (the Carolings, the Hohenstaufen); 2) the British concept of Europe as a 'contract' between sovereign countries with the primacy of parliamentarianism; and 3) the French conception of a 'Europe des patries' with republican dominance of politics over law. Essayist Karl Heinz Bohrer, a critic of Fisher's idea, wrote that this federalist idea undermines the 'forms of civilization represented by England or France.' He criticizes the Germans for their ignorance of the deeper levels of their European partners' cultures and the lack of empathy with which they impose their own vision of unity. It results, he claims 'firstly, from the distrust of their own nation and, secondly, from a romantic and not well-defined predilection for holistic ideas. ${ }^{9}$

The German approach to Europe and its values has been a long and painful process, including for others. The close connection of German spirituality and politics with the European model accelerated the integration of the continent around the mid- $20^{\text {th }}$ century. It was then that the phenomenon of united Europe really started - in the form of the European Economic Community and later the European Union.

8 J. Fischer: Vom Staatenverbund zur Föderation - Gedanken über die Finalität der europäischen Integration, http://www.zeit.de/reden/europapolitik/200106_20000512_fischer [access: 11.06.2010].

${ }^{9}$ K. H. Bohrer, Europejska specyfika. Epitafium dla pewnej niemieckiej utopii, [in:] Europejskie wizje..., p. 315-327. 
The expansion of the EU in 2004 to incorporate ten new countries ended the post-war and post-Cold War stage of integration and somewhat cooled the deliberations on the European project, but the unavoidable frictions in so large a community, together with its creeping crisis of confidence (not only regarding currency and taxes), has added fuel to the debate moving into the $21^{\text {st }}$ century.

The beginning of the new millennium started with a quarrel within Europe. The American war against terrorism divided European governments and the reaction to the Iraqi war in 2003 revealed different standpoints and sympathies. Eight states, including EU candidates (the Czech Republic, Hungary, and Poland) supported the Americans and found themselves in opposition to the official policy of Germany and France.

In fact, this political duality got into the public eye mostly in the two main continental countries of so-called 'old Europe.' In May 2003 daily newspapers in several European countries published an article by two prominent intellectuals, Jürgen Habermas and Jacques Derrida. In rather high-flown language, they diagnosed the new situation of the West with respect to a war that was causing the disintegration of Europe. Their firm condemnation of the war policy of the US administration was accompanied by an affirmation of international law and a call for quicker integration of the European core as a counterbalance to the "hegemonic unilateralism of the US. ${ }^{10}$ In their diagnosis the philosophers said: 'A gap is growing between the continental countries (Germany, France) and the Anglosaxon ones (USA, UK) but also between the 'old Europe' (Germany, France) and the East European candidates for the accession.' This statement was intended to highlight the immaturity of Poland, the Czech Republic and Hungary for such political participation which, in the EU, would not be in accordance with the political stance of the EU core. While the criticism of the US administration was acceptable and shared by many, Habermas and Derrida's anti-American tone was nevertheless excessive; it was a reflection of the German and French aversion to the allied superpower. They seemed to forget that less than a year before it was the American army that liberated Europe from a war, this time in the Balkans. Equally illusory was the turn towards the $\mathrm{UN}$, which as an organization is not very efficient, mainly as a result of egoistic policies pursued by over two hundred national subjects.

The authors of these words were projecting a new European reality, assuming as unavoidable the division into a 'core' and 'periphery' and trusting in the democratic order of secularized societies which, in public life, adhere to the principles of the welfare state and do not accept violence in foreign policy. This is why America, with its different priorities, lost its appeal as a model. The Europeans

10 J. Derrida, J. Habermas, Europa, jaka śni sie filozofom, „Gazeta Wyborcza” 10.06.2003, the internet edition: http://wyborcza.pl/1,103981,7470650,Europa_jaka_sni_sie_filozofom.htm1 ?as $=1 \&$ startsz $=\mathrm{x}$ [access: 19.09 .2011$]$. 
would go for readiness to co-operate, for being receptive to other cultures, for dialogue. Their priority and their challenge for the future was becoming the defence of a cosmopolitan order based on international law.

And it was precisely this cosmopolitanism which was the key notion in the concept devised in the first decade of this century by the prominent sociologist Ulrich Beck. He believes that Europe needs reinvention - for 'there is no Europe as such; there is only europeanisation in the sense of an institutionalized process of constant change. ${ }^{11}$ So far, European integration has been possible as long as the priorities of particular member states have been preserved. Considering the scale of the Union and the challenges facing it (economic, ecological, financial, social), it is essential to move to a higher level. This is also forced by the new means of communication and network information management which is beyond the control of individual states. The German authors support a 'cosmopolitan Europe.' This notion implies rejection of the 'either-or' logic in favour of a 'both-and' approach. Therefore, the key issue now is how to build - without the traditional stabiliser of the state and nation - and consolidate a new type of society and politics going beyond the well-known and traditional determinants. And so, ask Beck and Grande, how will social and political integration be possible through cosmopolitanization? And how can a horizon open up for it when the fundamental social and political forms and notions - society, state, politics, social inequality, mobility, ethnicity, justice, solidarity etc. - are freed from national orthodoxy and redefined in a cosmopolitan perspective?' They believe that this can only be possible in a Europe as 'an open political project,' in which Europe 'will be forming itself.'

In 2005 Beck and Anthony Giddens wrote: ' The European Union should be no longer perceived and misunderstood as 'an immature nation' or 'imperfect federation.' Historically, it is a totally new cosmopolitan project. Many fear, quite rightly, a superfederation. An inspirational Europe cannot be built on the ruins of its nations. The further existence of numerous states is a condition for a cosmopolitan Europe, and for the reasons already mentioned the converse is also true: without a cosmopolitan Europe national states are doomed to extinction. ${ }^{12}$

With the division in public opinion on the issues of acceptability of war, attitudes towards the neoliberal economy destroying the social tissue, and the pace and scope of the European integration, intellectuals' voices were heard more clearly. One of the most active was the philosopher Jürgen Habermas, who since mid $20^{\text {th }}$ century has published many articles, essays and discussions on European unity and a global civil society. Following the rejection of constitutional treaties in France and the Netherlands in 2003, the philosopher sees Europe stuck

${ }^{11}$ U. Beck, E. Grande, Europa kosmopolityczna. Społeczeństwo i polityka w drugiej nowoczesności, Scholar, Warszawa 2009.

${ }_{12}$ U. Beck, A. Giddens, Europa kann nicht auf Ruinen der Nationen errichtet werden, http:// www.welt.de/print-welt/article168315/Europa_kann_nicht_auf_den_Ruinen_der_Nationen_errichtet_werden.html [access: 10.08.2011]. 
in an analysis paralysis. And a paralysed European Union will not be able to cope with market dynamics and global challenges. For the first time in the history of united Europe 'we are facing the threat of stepping back in our integration. ${ }^{13}$ And so there is a risk that the European Union may transform itself into a regional free-trade zone of little importance. Given the current globalization processes, this would marginalize the Old Continent permanently.

In the summer of 2011, in the middle of the eurozone crisis, Jürgen Habermas gave a talk at Humboldt University in Berlin which was quickly picked up by the opinion-moulders - media, people and institutions. ${ }^{14}$ It also animated Europeans in general. In it, Habermas accused the German political elite of breaking the obligation to bring the Union closer to its citizens. At the same time, he formulated conditions for completing the European project as a political task. Habermas argued that in the same way that, following the cataclysm of World War II the idea of European unification expressed 'pacification of the bleeding continent', so too today it 'manifests an effort to hammer out the ability to act.' 'In this way, the nations of the economically and politically weakening continent are trying to keep some political leeway against the superpowers in the face of the systemic pressures of a global society.' The philosopher severely criticized Angela Merkel's government which, in his opinion, is drifting towards 'alleged national normality' and sacrifices the project of a united Europe for narrow German interests, with the result that '[t]he virtues of the 'old' Federal Republic have faded.'

For Habermas, the overriding aim is 'a political system for the global society,' for which the Union is an important stage. He claims that through the expansion and constitutionalization of the EU important innovations have already been implemented, which have changed the classic interpretation of sovereignty. One is 'subordination of the state monopoly of power to the primacy of supranational law; another is "extension of the classical constitutional subject - community of citizens - to include 'a "treaty community of states" with a mandate from its nations to co-build a supranational structure.' This is, in fact, how the Union operates - its members are states but their competences are limited by the Union law. At the same time, the citizens of those countries have sovereignly imposed on their governments the obligation of integration. Given the complexity of the challenges and the diminishing freedom of effective independent action by nation states, expansion of political action beyond national borders not only seems rational but 'results from the normative sense of democracy itself.'

Habermas dreams of Union citizenship and a European constitution. Knowing that this is hardly realistic at this stage, he opts for using the construct of a 'divided sovereignty,' whereby, on the one hand, the sovereign is comprised of the citizens

13 J. Habermas, Ach, Europa. Kleine Politische Schriften XI, Suhrkamp, Frankfurt am Main 2008.

14 J. Habermas, Europa am Scheideweg, „Handelsblatt“" 18.06.2011; J. Habermas, Wie demokratisch ist die EU?, „Blätter für deutsche und internationale Politik“ 8/2011, p. 37-48. Also http://www. blaetter.de/archiv/jahrgaenge/2011/august/wie-demokratisch-ist-die-eu [access: 22.08.2011]. 
of their own national states, and on the other - it is comprised of the states themselves when making decisions in the Council of the European Union. In both cases it is the political will of citizens which is realised, as 'individuals' and as 'members of state-nations (Staatsvölker).' Within this logic, it is rational to demand that the law-making subjects not be the member states themselves, but their nations. Then the Union would be no longer perceived as a project of political élites, implemented over people's heads somewhere in Brussels. Also, 'Union citizens' could then influence directly (and so not through their national states) the European Parliament's decisions in Strasbourg and those of other European bodies. For Habermas, such a change could be a chance to move the integration from the level of everyday management to a deeper involvement of citizens.

If citizens became a co-subject, their sense of participation in European politics would be enhanced immensely. 'It is in the logic of the constitution that citizens who have to share burdens which go beyond national borders would also like - in their role as Union citizens - to have a democratic say in what their leaders negotiate or decide in a legal grey area.' This creates an excellent warranty for political consolidation, which is after all the aim of integration. Once again, Habermas calls for stronger political integration, for example, of the members of the currency union. Concealing a financial meltdown and refusing citizens the right to affect decisions about unusually high expenses leads to populist anti-European attacks and could even bring about the destruction of the European project. People find it hard to accept the requirement of transnational union solidarity and trust in politicians' decisions if they are refused honest information and co-responsibility.

Toward the end of 2011 Habermas published a lengthy essay entitled Zur Verfassung Europas, which could be translated as either 'on the European Constitution' or 'on the state of Europe.' The single volume includes the pro-European interventions of the German philosopher. He is firmly against 'executive federalism', which looms out of the intergovernmental agreement for the eurozone debt crisis resolution. ${ }^{15}$ This, he warns, will 'hollow out' democracy even more, and the exclusion of citizens from a decision-making process with such serious consequences will ruin the European project permanently, instead of developing it towards a 'politically-constituted global society.' With the domination of markets over politics in the current financial crisis, politicians tend to force only those solutions which are seemingly more effective. Thus, a common economic government or a common Ministry of Finance is being formed without civil participation, and this approach totally ignores the 'parliamentarisation of financial policy.' With the eurozone governments (led by Germany) trying to bring the situation under control by strictly technical means, the Union is facing a crucial choice: between on the one hand injection of the democratic principles on which national states are built into the Union as a whole; and on the other hand a "post-democratic

\footnotetext{
15 J. Habermas, Zur Verfassung Europas. Ein Essay, Suhrkamp Verlag, Berlin 2011.
} 
executive federalism.' This choice will decide the fate of the whole integration project. Only by choosing 'transnational democracy' - as in Habermas's model - will it be possible to successfully defend integration.

Therefore, the main issue today is not the extension of the democratic legitimacy of EU through extending the prerogatives of the European Parliament, but the rescue of the Union and the increase of its democratic potential. To achieve this, Habermas wants the guaranteed primacy of 'supranational law over the national law of state monopolists' and the 'division of constitutional power between EU citizens and European nations.' Habermas is consistent in his demands for the constitutionalisation of the European Union and the introduction of real European citizenship. In this model each EU resident would have dual citizenship - Union and national. This would make him or her a dual sovereign and in this way the model of 'transnational democracy' would be accomplished. The ultimate aim for the German thinker is the transition from the present-day international community to a 'cosmopolitan community.'

In Habermas's view, 'united Europe' is a political phenomenon, the future of which depends on the extension of the democratic basis of its political acceptance. The projects of élites would, hopefully, turn into a community which, when allowed grass-roots participation, would be ready to make considerable sacrifices in order to follow a common policy in various areas and to show solidarity with other fellow citizens in critical situations in the whole 'cosmopolitan area'. The current challenges have considerably weakened national states' sovereignties, and the most important global decisions (particularly economic and financial) have been taken for years outside of democratic control. The division of sovereignty between the member states and the Union will not lessen their influence on decisions. Such an extension of democracy to the European level will become institutionalized in the dual citizenship of each EU resident, utopian as it may sound today. In his appeal for more democracy and responsibility the German philosopher refers to the theses of Kant from two hundred years ago. Habermas would like to see the EU as a milestone towards a politically-based and constitutionally-authorized world society. For the German intellectuals quoted above, Europe is not a geopolitical fact whose status quo needs reinforcement - it is a value as a utopian project of a political community emerging in the process of the europeanisation of the citizens and states of our continent. 